\title{
Supervision of Learning in Online Learning Perspective in the Pandemic Era of Covid 19
}

\author{
Jaenem Jaenem ${ }^{1, *}$,Zulkifli Zulkifli ${ }^{2}$
}

\author{
1,2 STKIP PGRI West Sumatera, Padang, Indonesia \\ *Corresponding author. Email: jaenam@stkip-pgri-sumbar.ac.id
}

\begin{abstract}
Physical separation between teacher and learner activities and no face-to-face presence are the characteristics of the online learning system that must be implemented by the teachers during the covid 19 pandemic. Therefore, the implementation of learning supervision carried out by the principals is focused on assisting teachers in developing learning planning skill, monitoring, using strategy, and making reflection. This study aims to describe the perceptions of PPKN teachers on the implementation of learning supervision in the perspective of an online learning system. This research was conducted with a quantitative approach. The research population is PPKn teachers at State Junior High School (SMPN) of Padang City totaling 150 respondents and the sample of 45 respondents is determined through a professional random sampling approach, which is $30 \%$ of the total respondents. Data was collected using a closed questionnaire with five alternative answers and analyzed through descriptive statistics assisted by SPSS software. The results of this study showed that the implementation of learning supervision in developing learning planning skills is in the enough category with an achievement level of $79.80 \%$, monitoring is in the enough category with $77.85 \%$, using strategy is in the enough category with $78.69 \%$, and developing reflection skills is enough category with $78.79 \%$. Thus, the level of implementation of learning supervision reached $78.78 \%$ of the ideal score and it was in the less wellexecuted category. According to respondents, the supervision of learning in online learning perspective in the pandemic era of covid 19 is quite good.
\end{abstract}

Keywords: Covid 19, Online Learning, Supervision of Learning.

\section{INTRODUCTION}

Supervision of learning is often or even always seen as an unpleasant principal program, even very scary for teachers. What the teacher imagines about learning supervision is the weaknesses or shortcomings in carrying out learning will be identified and he will be labelled an unprofessional teacher. Indeed, what often happens is that the principal supervises learning in order to find out who is wrong in carrying out learning, not looking for what is wrong in the implementation of learning.

Learning supervision is a must, on the one hand learning supervision is carried out in order to provide input for teachers, so that they are able to maintain and improve the effectiveness of learning. Supervision of learning is often described as a key component to the formation of good teachers, effective teachers, and excellent teachers. Learning supervision is one of the activities planned to help teachers in carrying out their work effectively [1]. Many studies have ended in the conclusion that effective learning supervision is very influential on teacher achievement. Moreover, research shows that effective learning supervision has a major influence on teacher performance in carrying out learning tasks. On the other hand, the supervision of learning carried out needs to be adjusted to the conditions of learning carried out by the teacher. In the current Covid 19 pandemic conditions, the implementation of learning is no longer done in the classroom, but online.

Changes in the approach to the learning process require teachers to make changes in learning strategies from face-to-face learning in class to distance learning that is carried out online. By this, principals must be able to supervise learning as an important part of education management [2] to help teachers plan learning, monitor, use strategies and reflect on online learning. Helping teachers to carry out online learning is part of the principals' performance in carrying out their main tasks in accordance with the mandate of Permendikbud 
Number 6 of 2018 which states that the principals' main task is to supervise teachers.

The main target of online learning supervision is in order the teachers can develop their potential to be creative and improve their performance in online learning. However, there are often many factors that prevent them from developing their various potentials optimally, especially in the implementation of online learning. The main function of learning supervision is to improve the learning situation to be better. Therefore, it is needed the continuous learning supervision and directed and systematic program in helping teachers to carry out learning.

Learning supervision is very decisive in realizing a quality online learning process. Of course, this can be realized if the principals have a good performance in carrying out learning supervision so that it can help teachers carry out online learning effectively. To determine whether the principals have a good performance or not in carrying out the supervision of learning, it is necessary to carry out an assessment, especially an assessment by teachers who are supervised by the principals in online learning. Especially professional services carried out by principals, supervisors, and other supervisors to improve school quality. The purpose of these professional services is to improve the quality of learning processes and outcomes so that the planned educational goals can be achieved.

Performance appraisal is a structured formal interaction between subordinates and superiors in identifying weaknesses and strengths as well as opportunities for improvement and skill development [3]. With the assessment of the principals' performance by the teacher or often also referred to as the teachers' perception of the principals' performance in the implementation of learning supervision, it is a cognitive process experienced by the teacher in understanding and receiving the guidance carried out by the principal. The teachers' perception plays a very important role in assessing the performance of the principals, from this perception it can be seen whether the principals have implemented it in the right position related to the implementation of learning supervision tasks. Teachers certainly have their own perceptions of the performance of the principals in carrying out the task of supervising learning, because perception is a way of assessing based on the experience of existing objects or experiences that have been experienced by theories and beliefs that have. Perceptions that arise can vary among teachers, some have a positive perception and some have a negative perception of the aspects they are assessing.

Teachers as the main component in providing quality learning services are required to have competence in accordance with the development of information technology. The rapid development of information technology, educating is a tough task and requires someone who is able to empower information technology in carrying out learning. The role of information and communication technology in learning, including the online learning system is very important. Online learning is a program for organizing online learning classes to reach a massive and broad target group [4].

Several studies have shown that information technology has a positive influence on the implementation of learning. Gheytasi [5] states that students who interact a lot with information technology in learning more easily understand the subject matter. The implementation of online learning is a learning model that is carried out during a pandemic, because the principle of education during the Covid 19 pandemic is to prioritize health and safety in the implementation of learning. Online learning is a learning system without face to face directly between teachers and students but is carried out online using the internet network [6].

The basic difference between online learning and face-to-face learning is in the media where an instruction is run. In the face-to-face method, the teacher has full control over the environment where the teacher will make all changes whenever the teacher wants, and the quality of material delivery is still strongly influenced by several things including the ability and the personality of the teacher, the process of adapting to the surrounding environment and making modules as supporting materials. While in online learning teachers and students undergo the learning process from different places, where the ability to adapt and change is no longer available [7]. As a result, many teachers stutter to face these differences in the implementation of learning. Muhdi and Nurkolis [8] states that in online learning system, there are several obstacles that are considered less effective, such as the provision of learning materials by teachers, technology literacy from teachers and parents who will guide children, and the economic situation of children.

The main abilities that teachers must have in carrying out online learning are planning lessons, monitoring, using strategies and reflecting online learning [9]. However, some research results ([10], [11], and [12]) state that the implementation of learning during the Covid 19 pandemic shows that during the pandemic online learning is less than optimal. This should be the main concern of school principals. The results of research ([13], [14], and [15]) found that the importance of the principals' leadership role in learning succession and improving teacher discipline. One of the principals' leadership roles in addressing these problems is to carry out learning supervision.

In the context of online learning, the intended learning supervision is to develop the ability of teachers to plan lessons, monitor, use strategies and reflect online learning so that the implementation of online learning in the era of the Covid 19 pandemic can be carried out properly.

\section{THEORETICAL REVIEW}

During the Covid 19 pandemic, the empowerment of information technology in learning is a must to prevent the spread of Covid 19 in school clusters. The role of information and communication technology in learning, including the online learning system is very 
important and able to provide convenience to teachers and students in the learning process. The term online is an acronym for "in the network" which is an activity carried out with an online system that utilizes the internet. Online learning is a program for organizing online learning classes to reach a massive and broad target group [4].

Gheytasi [5] states that students who interact a lot with information technology in learning more easily understand the subject matter. The implementation of online learning is a learning model that is carried out during a pandemic, because the principle of education during the Covid 19 pandemic is to prioritize health and safety in the implementation of learning. Online learning is a learning system without face to face directly between teachers and students but is carried out online using the internet network [6].

Teachers as the main component in providing quality learning services are required to have competence in accordance with the development of information technology. The main abilities that teachers must have in carrying out online learning are planning lessons, monitoring, using strategies and reflecting online learning [9]. This should be the main concern of school principals. One of the principals' leadership roles in addressing these problems is to carry out learning supervision. Supervision of learning in the online learning perspective ([16], [17], [18], and [19]) is the provision of services to teachers in an effort to help develop the ability of teachers to improve the quality of learning. Academic supervision is defined as a series of activities that help teachers develop the ability to manage the learning process to achieve the learning objectives. Academic supervision is inseparable from the performance appraisal of teachers in managing learning [20].

\section{METHOD}

This study uses a descriptive quantitative approach to describe teachers' perceptions of the implementation of online learning supervision at State Junior High School (SMPN) of Padang City. The respondents in this study were PPKn teachers totalling 150 respondents. The sample was set at $30 \%$ and the number of respondents using a proportional random sampling technique approach, namely 45 respondents.

The data collection technique were carried out using a Likert scale questionnaire via google form and analyzed descriptively in percentage form with the formula as follows [21]:

$$
P=\frac{\sum \text { score }}{\sum \text { ideal score }} \times 100 \%
$$

The criteria for achieving learning supervision performance according to respondents' perceptions are as follows:
$91-100$
$86-90$
Very Good
Good

$\begin{array}{ll}75-85 & \text { Enough } \\ 66-75 & \text { Moderate } \\ 46-55 & \text { Less }\end{array}$

\section{RESULTS AND DISCUSSION}

The empirical data described in this study relate to respondents' perceptions of the principals performance in the implementation of learning supervision in the perspective of developing the ability of teachers to manage online learning processes based on indicators of online learning planning, monitoring, use of online learning strategies and reflections, as shown in Table 1 and Diagram 1 below.

Table 1. Helping the Development of Teacher Ability in Online Learning

\begin{tabular}{|l|c|c|l|}
\hline Indicator & Average & $\begin{array}{c}\text { Achievement } \\
(\mathbf{\%})\end{array}$ & Category \\
\hline Planning & 4,23 & 84.69 & Enough \\
\hline Monitoring & 4,64 & 92.73 & $\begin{array}{l}\text { Very } \\
\text { Good }\end{array}$ \\
\hline $\begin{array}{l}\text { Strategy } \\
\text { use }\end{array}$ & 3,25 & 64.95 & Moderate \\
\hline Reflection & 3,64 & 72.75 & Moderate \\
\hline \multicolumn{1}{|c|}{ Sum } & $\mathbf{3 , 9 4}$ & $\mathbf{7 8 . 7 8}$ & Enough \\
\hline
\end{tabular}

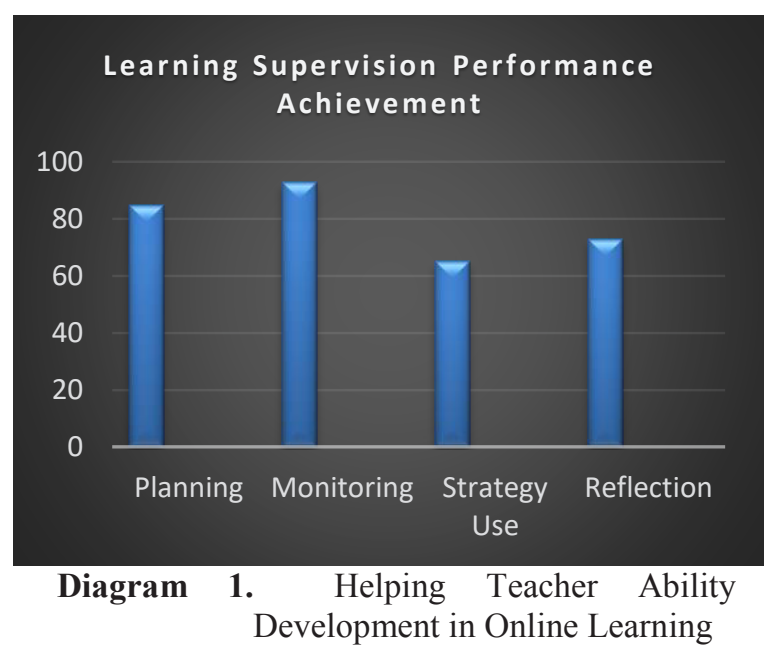

Based on Table 1 and Diagram 1 above, it can be seen that the level of achievement of respondents' perceptions of the principals performance carrying out learning supervision to help develop teachers' abilities in online learning is in the enough category $(78.78 \%)$. This means that the principals have implemented learning supervision quite well, but based on each indicator, especially the indicator of strategy use $(64.95 \%)$ and online learning reflection $(72.75 \%)$ have not been implemented properly. This finding is in line with the previous research ([10], [11], and [12] who state that the implementation of online learning during the Covid 19 pandemic was not carried out optimally.

The ability of teachers is a factor that influences the level of implementation of online learning. For optimal 
implementation of online learning, the principals must improve the ability of teachers well. Murfi [13], Elfidawati [14], and Mukhtar [15] found that the importance of the principals' role in learning succession and improving teacher abilities. The principal in carrying out his role to improve the ability of teachers can be done through the implementation of learning supervision. Mukhtar and Iskandar [16], Sagala [17], Imron [18], and Ubabuddin, [19] state that supervision of learning is the provision of services to teachers in an effort to help develop teachers' abilities to improve the quality of learning. The principals' performance in carrying out learning supervision to help develop the ability of teachers to carry out online learning during the Covid 19 pandemic, especially in the aspect of using strategies and reflection on online learning has not been carried out properly. For this reason, so that teachers have the ability to carry out online learning, it is expected that the principals make this findings as a reference for improving performance in the implementation of learning supervision.

\section{CONCLUSION}

From the results of the study, it was found that learning supervision in developing the teachers' ability to manage the online learning process in the aspects of planning, monitoring, using strategies, and reflecting according to PPKn teachers had not been implemented properly. For the implementation of good supervision of learning, the principals need to have an understanding of online learning planning, monitoring, use of good online learning strategies and reflections, so that the principals can develop the teachers' ability to manage the online learning process.

\section{AUTHORS' CONTRIBUTIONS}

Jaenam focused on developing online learning theory and Zulkifli focused on learning supervision theory. In terms of methodology, Jaenam contributed to develop online learning instruments and Zulkifli contributed to develop supervision intruments. Both authors jointly collected and analyzed data from the respondents. Jaenam described the research findings and Zulkifli contributed to the interpretation of the results. Both authors discussed the result and contributed to the final manuscript.

\section{ACKNOWLEDGMENTS}

I would like to thank the head of STKIP PGRI West Sumatera and the Padang City Education Office, especially the PPKn teachers who have facilitated the implementation of this research.

\section{REFERENCES}

[1] P. A. Sahertian, Konsep dasar dan teknik supervisi pendidikan dalam rangka pengembangan sumber daya manusia. Jakarta: Rineka Cipta, 2000.
[2] U. Usman, Menjadi guru profesional. Bandung: Remaja Rosdakarya, 2007.

[3] D. A. Kurniady and Suryadi, "Model penilaian kinerja (performance appraisal) kepala sekolah menengah pertama negeri," in Ilmu Pendidikan. Available:

http://ejournal.upi.edu/index.php/pedagogia/art icle/download/5896/3980, 2017.

[4] Y. Bilfaqih and M. N. Qomarudin, Esensi pengembangan pembelajaran daring. Sleman: Deepublish, 2015.

[5] M. Gheytasi, A. Azizifar, and H. Gowhary, "The effect of smartphone on the reading comprehension proficiency of Iranian EFL learners," Procedia - Social and Behavioral Sciences, 199, p. 225-230, 2015.

[6] D. Evayanti, "Efektivitas pembelajaran melalui metode daring (online) dalam masa darurat covid-19." Available: https://www.stitalkifayahriau.ac.id/efektivitas-pembelajaranmelalui-metode-daring-online-dalam-masadarurat-covid-19/, 2020. [Accessed on January 5, 2021].

[7] A. A. Hamid, "The internet and higher education, 4 (3-4), p. 311-316, 2001.

[8] Muhdi and Nurkolis, "Keefektifan kebijakan elearning berbasis sosial media pada PAUD di masa pandemi covid-19," Jurnal Obsesi: Jurnal Pendidikan Anak Usia Dini, 5 (1), p. 212-228, 2021.

[9] D. Y. Kristanto, Upaya peningkatan kualitas pembelajaran Matematika melalui flipped classroom dan gamifikasi: Suatu kajian pustaka: PRISMA: Prosiding Seminar Nasional Matematika, 3, p. 266-278, 2020.

[10] W. Wargadinata, I. Maimunah, E. Dewi, and Z. Rofiq, "Student's responses on learning in the early covid-19 pandemic," Tadris: Jurnal Keguruan dan Ilmu Tarbiyah, 5 (1), p. 141-153, 2020.

[11] M. A. M. Prasetyo, B. Bashori, and N. N Lailisna, "Strategy of boarding school (pesantren) education in dealing with the covid19 pandemic," Khalifa: Journal of Islamic Education, 4 (2), p. 142-160, 2020.

[12] W. Adisasmito, How Indonesia is expediting its response to covid 19, Jakarta Post, 2020, 28.

[13] A. Murfi, Faturrochman, A. Atika, and N. S. Jannana, Kepemimpinan sekolah dalam situas kritis covid 19 di Indonesia, Manageria: Jurnal Manajemen Pendidikan Islam, 5 (1), p. 119136, 2020.

[14] E. Elfidawati, Peningkatan kedisiplinan dan kualitas pembelajaran guru pada masa pandemi covid 19, 2020.

[15] H. Mukhtar, and M. A. M. Prasetyo, Pesantren efektif model teori integratif, 2020.

[16] Mukhtar and Iskandar, Orientasi baru supervisi pendidikan. Jakarta: Gaung Persada, 2009.

[17] S. Sagala, Supervisi pembelajaran dalam Profesi Pendidikan. Bandung: Alfabeta, 2010.

[18] A. Imron, Manajemen peserta didik berbasis sekolah. Jakarta: Bumi Aksara, 2011.

[19] Ubabuddin, Meningkatkan kinerja guru melalui supervisi pembelajaran, Ed-Humanistics, 4 (1), 2019. 
[20] C.D. Glickman, S.P. Gordon, and J.M. RossGordon, Supervision and Instructional Leadership A Development Approach (Seventh Edition). Boston: Pearson.

[21] Sugiyono, Metode penelitian dan pengembangan research and development.

Bandung: Alfabeta, 2015. 